\title{
How Emerging Markets Are Reshaping Globalization
}

\author{
Kreshnik Aliaj ${ }^{1}$ \\ ${ }^{1}$ Horizons University, France \\ Correspondence: Kreshnik Aliaj, Horizons University, France. E-mail: kreshnik.k.a1980@ gmail.com
}

Received: December 2, 2018

Accepted: December 24, 2018

Online Published: January 10, 2019

doi:10.5539/ijef.v11n2p111

URL: https://doi.org/10.5539/ijef.v11n2p111

\begin{abstract}
Globalization is a hot topic of the day. Not a day goes by without us being overwhelmed by the overwhelming news resulting from this all-out integration: relocation of jobs to countries where working conditions are too often unacceptable, closures of companies due to overly intense global competition, deterioration of the environment resulting from unbridled production, etc. In addition, workers' worries about the consequences of China's growth in the world of work are added. In this age where finance is queen and dictates the behavior of business leaders, where companies close their doors even if their business is good, where national champions are bought without the governments do not lift a finger, where Savers are robbed by unscrupulous financial actors who remain unpunished, the world seems more uncertain than ever. Recently, the world seems to have entered an era of great turbulence: unprecedented financial scandals which in their wake lead to many job losses; real estate and financial crises in the United States that threaten the balance of the global economy; rising food prices and violent protests in several developing countries. And international institutions, supposed to manage these crises, seem powerless to contain them.
\end{abstract}

Keywords: globalization, market, reshaped, economy, crises

\section{Introduction}

Globalization is a reality of our contemporary economies. Although it appears in many ways to be an irreversible process, the fact remains that it is the subject of discussion and criticism. Among economists, one of the most virulent criticisms of the excesses of globalization is Joseph Stiglitz, Nobel Prize winner in economics. Yet he also sees the benefits when he writes, "I am confident that informed citizens will be more likely to exercise some control to limit the abuse of particular, financial and industrial interests, which have so dominated globalization, and that the ordinary citizens of the advanced industrial countries and those of the developing world share a common interest in making globalization work". (Stiglitz et al., 2012).

A strong advocate of globalization is Jagdish Bhagwati. This internationally recognized specialist in trade protectionist policy highlights in his various books the benefits of globalization. However, far from defending unbridled globalization, Bhagwati recognizes the existence of losers in this process, losers who must be subject to economic policy measures. It also stresses the need to accompany the globalization of strengthening governance.

According to the Multilingual Dictionary of the International Monetary Fund (IMF), it is the translation of globalization, but it is not uncommon for francophone authors to distinguish globalization from globalization. This term will become a clear media success of the 1990s. Soon the term will be adopted by politicians who are worried about the decline of states in the face of globalized firms; by international relations specialists who identify a new economic power and new tensions; by trade unionists who see it as the manifestation of the opposition between capital and labor.

Curiously, economists have long been reluctant to the idea of a specific economic analysis of this phenomenon, thinking that there were in the arsenal of theories of international trade and finance enough tools to interpret the changes observed in an economy that is globalizing. The first academy works will be done by Anglo-Saxon economists, then by international institutions.

It could not be said that there was a specific approach to globalization in economics as is the case for economic growth, international trade, development until the 1990s. There was rather an attempt by economists to provide analyzes of globalization by mobilizing economic history, international economy, industrial economy, geographical economy, financial economy, economic dynamics. Over the past fifteen years or so, the situation 
has changed: theoretical work has multiplied (Gopinath et al., 2014), new statistical data are available, books are published which provide summaries or insights into the future of the phenomenon of globalization. (Baldwin et al., 2013). We also note that the term globalization in economics is often associated with another term or an expression, thus introducing a multidimensional character of this process. For example, we will have globalization and financial integration; and development; and growth; and new economy; and migrations; and employment; and specialization; and location of activities; and governance; and inequalities.

\section{The Parallel Between Growth Analysis and Globalization Analysis}

It is interesting to compare the economic analysis of globalization with that of economic growth, because there are many similarities in the changes that can be made to these two dynamics.

Economic growth is based on the accumulation of factors of production and the technical progress, the expected effect is an increase of the product per capita but also with a modification of the distribution of the income related to the relative deformation of the demand of factors of production. Finally, the process underlying this growth dynamic involves a subtle combination of incentives based on the functioning of more or less competitive markets and efficient public policies that must allow the integration of external effects.

The globalization of economies brings with it a similar dynamic, but with one essential difference: the opening of economies replaces technical progress (the impulse would therefore be much less uncertain since it is achieved automatically when economies open to exchange) allowing an increase of the efficiency of the factors of production which is based this time on the specialization of the productions in each economy (the countries are reduced to blocks of factors of production).

This is the very essence of Ricardian analysis of international trade, which remains the keystone of economic theory in this field. Open markets create competitive pressure that distorts the relative price structure that encourages producers in each country to reorient their activities to the most profitable sectors, resulting in sectoral reallocation of factors of production that will allow an increase in factor productivity without the need to introduce technical progress 6 (economists will say that a border of higher production possibilities can be achieved through exchange and to specialization).

Of course, as with economic growth, these changes in factor use have implications for their relative earnings, which will translate into distributional effects that lead to losers and winners. Finally, to conclude this comparison, globalization and growth are, in fact, based on a delicate combination of the incentives generated by the opening of markets and the construction of public policies aimed at correcting the effects of distribution and to build new rules of the game to mitigate market failures.

This role of public policy contains all the ambiguity of the trade policies that are negotiated in international forums: the objective is no longer simply to achieve free trade (with imperfect and incomplete markets), but also to submit domestic public policies to discussions that seek to set the rules of the game by forcing states and international bodies to innovate to build policies that improve the governance of economies. Globalization is leading to a growing interpenetration between the international space and the space of national sovereignty.

Let us add that globalization and growth are not separate issues. We can see that the globalization phases are also periods of accelerating economic growth. The two phenomena are thus intertwined without it being possible to establish in an incontestable way a relation of causality. It is likely a favorable interaction that operates.

\section{Globalization Is not a New Phenomenon}

Amartya Sen wrote in 2001: "Globalization is not a new phenomenon, nor is it simply Westernization. For thousands of years, globalization has advanced through travel, trade, migration, expansion of cultures, spread of knowledge and discoveries (including science and technology). The influences played in various directions. Thus, towards the end of the millennium that has just ended, the movement has largely operated from the West, but in its beginnings (around the year 1000), Europe was absorbed Chinese science and technology, Indian and Arab mathematics. There is a global legacy of interaction, and contemporary movements are part of this story" (Sen, 2001). In fact, if the process is not new, it is the term, especially in its English version globalization, which designates a new phenomenon, that of the last wave of internationalization which marks the end of the twentieth century and the beginning of the xxi. Since the process is not new, it is legitimate to ask when globalization begins, if there are several globalizations and, if so, what are the differences?

Authors like Philippe (2004), Régis (2003), Daniel (2004), Dani (2011), Richard (2011) compare the different waves of globalization by showing that by its magnitude, the wave of the nineteenth century is of an intensity largely equivalent to what we observe today when we refer to the communications revolution, the migratory flows and the capital movements. 
If the globalizations of the nineteenth and twentieth centuries are comparable in their scale, we will have to show that they are differentiated by the processes of integration at work: the first is characterized by the intensification of international economic relations and the extension global markets in the context of "modern growth" centered on Europe and the New World (North America, Australia, New Zealand); the second is marked by the fragmentation of production processes that stimulates the industrialization of Asia, Latin America and part of Africa, the relative blurring of borders and the loss of autonomy of the political decision. New reflections are brought about by these unprecedented dimensions of the integration of economies in a context marked by the multiplication of tensions and the search for new forms of regulation of international economic relations.

\section{The Magnitude of the Last Two Waves of Globalization}

By their intensities, the two waves of globalization are comparable, the one that precedes the First World War and the one that emerges from the end of the 1970s. However, the comparison is biased by the choice of the generally adopted indicators. IE assessments of international flows of goods, migration flows and capital flows. Indeed, these flows concern exchanges in markets that will experience partial processes of integration as we will see in a first step. The reorganization of production structures that accompanies these globalizations with the resulting changes in the international division of labor are of a different nature; this will be the subject of our analysis in a second step.

\section{Integration of Goods Markets}

It was in the nineteenth century that the growth of merchandise trade between continents experienced an unprecedented acceleration. The volume of world trade, growing at a rate of $3.5 \%$ per year, will be multiplied by more than 25 over a century. More precisely, we are witnessing a decisive acceleration of international trade from the 1850s. If we take the example of Great Britain or France, we see that these economies around 1840 still have a relative importance of foreign trade compared to the national product which is comparable to that of the 1760 s.

The global growth of merchandise exports over the period $1870-1913$ is at an annual rate of $3.4 \%$, while the GDP for the world over the same period increases at an annual rate of $2.11 \%$. Over the entire nineteenth century, it can be said that international trade is growing twice as fast as production. This momentum of trade integration peaks on the eve of the First World War, with levels comparable to those found in the 1970s, and again, not for all regions of the world.

However, we must mention a bias when we present the long-term historical changes in the ratio of exports to GDP. This bias is due to the composition of GDP when we distinguish between tradable goods and services (manufactured goods, raw materials, etc.) and non-tradable goods and services at the international level (this concerns a significant part of the services), the latter occupying a growing share of national production, particularly for the economies of the countries that were the main actors in the wave of nineteenth-century globalization.

For example, we can now estimate, for France, that the ratio of international trade for tradable production is three times higher than the ratio of international trade to GDP. Returned to tradable production, the trade openness of the global economy today is much greater than that reached on the eve of the First World War.

\section{Integration of Labor Markets}

Standardized analyzes of globalization that focus on trade and financial flows generally reserve a secondary role for international migration. This can be understood by referring to the theory of neoclassical international exchange which presents international trade as a substitute for factor exchanges: it is because we do not have the same endowments in factors of production that we specialize. (Mundell, 2015) The exchange of goods replaces the exchange of factors. Yet the reality is different. The liberalization of trade in goods and services and the migration of workers, far from being substitutable, are rather complementary. However, we must add a nuance to this assertion, because for the poorest countries of the South that are excluded from trade and financial integration, their only visible participation in globalization is the flow of international migration to rich countries, in particular for skilled workers in these poor countries.

It should be added that the big difference between trade and migration is that the first concerns cross-trade between countries that are both importers and exporters, while migrations operate one way. (Panagariya, 2000) There is therefore a clear distinction between countries of origin and host countries, hence the difference between international trade analyzes based on the idea of mutual benefits and those focused on the differentiated effects of migration for countries. origin and for the host countries. In addition to migration, the differences between the individual impact of migrants and the effect at the collective level for countries should be added. 
If international migration is a dimension of globalization that can not be neglected, we must begin by assessing its importance over time. Since the discovery of the Americas, there has been a steady flow of international migration. Jeffrey Williamson and Timothy Hatton (Lipsey et al., 2000) estimate the number of migrants at 11.3 million before 1820, but this flow was mainly made up of African slaves ( 8.7 million), contract servants and convicts. Free workers were therefore a tiny minority of these migratory flows, which is easily explained by the high cost of the trip, which was long and risky.

With the wave of globalization in the nineteenth century, change is both in the type of migration (the share of free migrants increased from $20 \%$ in the 1820 s to $80 \%$ in the $1840 \mathrm{~s}$ ) and in the magnitude of the flow. It can be seen that from the 1840s to the 1870s, on average, the annual number of European immigrants was 300 000; it increased rapidly at the end of the nineteenth century to more than a million a year.

\section{The Integration of the Capital Market}

There is an official definition of FDI produced by the IMF in 1993 and adopted by the OECD in 1996, but this notion, which has evolved considerably over time (Lipsey et al., 2000), refers to two realities and also to two branches of economic analysis: the first is that of capital flows studied by international finance, the second is that of international investments studied by the industrial economy. It is this second aspect that we will now address through the internationalization of the productive capital factor.

In the 1990s, the increase in the share of FDI was all the more spectacular that it occurs during a phase of very rapid growth in international investment (they are multiplied by 6). However, there is an important difference between FDI of the late nineteenth century and the 1990s, the destination of these flows; it is no longer the developing countries that are the main recipients of FDI but Europe and the United States. Since the early 2000s, developments have been much more difficult, especially at the level of developed countries, which this time represent historically lower share since 2009 , less than $40 \%$ of total FDI, while they were still $57 \%$ of FDI in 2007.

Behind this change, there is first the rise of emerging countries and countries in transition that receive $60 \%$ of FDI in 2014 (despite a decrease in economies in transition where FDI inflows rise from 100 to 48 billion of dollars between 2013 and 2014), but especially which represent 39\% of FDI outflows against $12 \%$ in the early 2000s (reflects the rapid growth of international investment by multinationals in these countries). Since 2008, there has been a trend towards a slowdown in direct investment in Western economies that reflects both the fragility of the recovery in these economies and the cautiousness of investors who prefer to postpone their decisions.

\section{The Effect of Globalization in Migration Dynamics}

Migration, the third largest factor in global integration, stands in sharp contrast to trade and it's dynamics. In contrast to global trade where it has been seen that the barriers to it have fallen greatly over these 150 years, the opposite has occurred with migration issues, which seem to have grown significantly and progressively. In economic terms, this phenomenon is quite complex, because recent gains from international migration outstrip trade gains. Globalization wipes the boundaries between states and the ease of capital movement brings formal elimination of boundaries between global labor markets. Global job market trends can be seen in the context of the free movement of the population and labor force, as well as through international manufacturing integration.

These tendencies can be rationalized (though not necessarily justified), by the fact that migration has more important social consequences. It is the perception of these social effects rather than the economic benefits of migration or distribution implications, which play a greater role in determining policies. Putting the focus of social consequences rather than economic ones, the impact of migration effects has led the country to have less to give than to take, as countries of origin have little to offer in the form of mutual concessions. It seems, then, that international agreements have little impact on immigration policy. The new flexible forms of employment result in reduced labor costs and capital costs and increase labor mobility. These flexible forms of work relationships cause a large number of controversies and controversy in society. Loss of employee safety in terms of labor market elasticity leads to the economic insecurity of employees, frustration and a variety of social tensions. Regardless of the substantial amounts payable on the principle of free movement of workers, regional agreements have done little to reduce the barriers to this phenomenon (except for European Union). Bilateral agreements have facilitated legitimate migration by low-skilled workers, but recent deals have covered only a small number of workers, especially compared to the number of illegal immigrants coming from the same countries of origin. Apparent breakthroughs in this regard seem to have only been done by Germany, and that in the last year (2018). 
But what are the consequences to those high barriers of immigration and emigration? High barriers to immigration have had different results in different countries. In many countries, the restrictions are only partially effective, resulting in illegal immigration, reduction of welfare benefits from migration and lowering respect for the law and social values. This produces this situation: richer states choose to give up substantive economic benefits from emigration in an effort to achieve social goals, but they create a major social problem, illegal immigration, in the process and they lose resources in efforts deplorable implementation, making immigrants more vulnerable to physical hazards and abuse. Today's emigration policies create major social problems, as we also stated above, while significantly reducing the benefits for rich countries, poorer countries and immigrants. As developing countries become more important in the global economy, their ability to benefit migration experience for their citizens will also improve. For example, they will be able to give them consular representation as well as information on the dangers and opportunities in emigration. And they continued urbanization will increase migrant supplies by disseminating information on migration opportunities and the breakdown of social networks. Meantime, small and developing countries will develop their immigration policy, and many are becoming an important destination for migrants. The responsibility for correcting these issues lies directly on the shoulders of large countries. A more rational immigration policies can not only improve global well-being, but can also help create more peaceful and productive societies in rich countries. In particular, destination countries should integrate society by embracing their migrants rather than penalizing them. In Europe this means that the descendants of immigrants have genuine economic opportunities. In the United States, this means stepping out of increasingly popular, but fully bankrupt support in police actions to control illegal immigration. International co-ordination can only play a secondary role, although progress is possible in areas that enjoy broad support. (Williamson, 1990).

\section{The Disproportionate Nature of Economic Growth under the Aegis of Globalization}

Economic performance and economic development in any way is not guaranteed, we must bear in mind that in fact the centuries of economic stagnation have determined most of the history. Although the causes of this long-lasting economic hibernation are the subject of a long-standing debate, stagnation, at its core, is likely to be accompanied by a major technological progression. Global economic output expanded slowly when peoples grew and people spread from China to other parts of Asia and from Europe to America. This "broad" economic growth is significantly different from the "intensive" growth in today's economies, resulting from rising productivity levels. Added trade provided a channel for raising the standard of living, especially in Europe and its colonies, although trade progress was also extremely slow. The gradual technological upgrades allowed some societies to grow temporarily forward. However, these improvements failed to provide permanent or immediate benefits. Improvements also failed to reach other societies, countries and economies in the world. The technology spread only after successful civilizations grew and populated, but the smaller venues rarely adopted upgrades or varieties. As the population grows, as food production rises, marginal land returns and every workplace decrease, while lowering the standard of living standards. This relationship, in which the population size and standard of living move in the opposite way, is commonly known as the "Malthusian Trap". Proponents of this theory argue that in the absence of technological advancement, visible increases in standard of living can only occur if the population falls, one of the greatest plagues of the fourteenth century. Although some historians question this theory, (Clark \& Farewell, 2008), little disagreement has the theory that revenues grew shortly before the Industrial Revolution. The modest and sustainable economic growth, well-known to citizens in modern economies, is a recent phenomenon that has only reached a limited number of states. (Clark \& Farewell, 2008).

\section{The Evolution of World Trade}

Globalization has profoundly changed the structure of world trade, with new players taking up more and more space. Because multilateral negotiations at the World Trade Organization (WTO) 1 are stalled, many countries, including Canada, are turning to the negotiation of bilateral agreements.

Free trade policies have had remarkable effects on the growth of exports and on economic growth in general. Between 1990 and 2006, the growth rate of world exports grew at an average annual rate of 6\%, while world gross domestic product (GDP) grew by $2.4 \%$.

Trade still continues to be very predominantly between rich countries. Thus, most of the world trade is between the industrialized countries and is mainly a neighborhood trade. For example, Canada is the largest trading partner of the United States. In the European community, France, Italy, the Netherlands and England are the main trading partners of Germany, the current world export leader.

Between the mid-fifties and the seventies, the share of developing countries in the exports of rich countries 
continued to decline. Even today, rich-country exports to poor countries account for only $2 \%$ to $3 \%$ of their gross domestic product (GDP). In contrast, exports from poor to rich countries are five times larger. However, the share of these countries in trade remains, for the moment, well below their demographic weight.

However, recently, several emerging countries have significantly increased their weight in the global economy. Moreover, a new trend is emerging with respect to the national origin of the 78,000 transnational corporations operating around the world. Of the top 100, 48 are from the United States and much of the industrialized world. But transnational companies are developing in emerging countries and rising in the world rankings. Their development is no longer based solely on low labor costs. Their research and development efforts, although still at low levels compared to those of transnational corporations in the North, are on the rise.

The signing of free trade agreements or economic partnerships is one of the tools available to governments to promote exports. The Government of Canada is an uncritical adept of the benefits of economic integration to the point of making it a kind of religion. Since the stalemate in multilateral discussions at the World Trade Organization (WTO) and the Free Trade Area of the Americas (FTAA), Canada has focused on bilateral negotiations, with several agreements signed, others being negotiated.

In addition, in the name of security, Canada, the United States and Mexico have begun negotiating a Security and Prosperity Partnership of North America (SPP). Launched in March 2005, the Partnership is about going beyond the North American Free Trade Agreement (NAFTA), developing common security and border control policies, harmonizing many national policies and product and service regulation (most often to US standards), but most importantly to ensure a strong integration of North American energy markets.

Thirty or so of North America's largest corporations are grouped into the North American Competitiveness Council (NACC), which provides the private sector with bargaining power. The labor movement is out of place, not even Canadian parliamentarians. As the Partnership is not a formal treaty, there is no obligation to submit it to the debate or to have it ratified by Parliament.

The Quebec government is also showing boundless enthusiasm for the logic of free trade. At all platforms, in all government documents and speeches, and to respond to all the economic ills of Quebec, the government praises free trade and caresses the ambitious project of creating a new economic space. Two aspects of the government's strategy are directly related to trade liberalization: the conclusion of a free trade agreement with Ontario modeled on an agreement signed between Alberta and British Columbia (TILMA) and the promotion of an economic partnership between Canada and Europe.

In both cases, the Quebec government is seeking to eliminate the barriers that hinder trade, but also the mobility of labor. In most industrialized countries, there is a tighter labor market, and even labor shortages, particularly as a result of the aging of the population. Businesses, rather than changing their sometimes discriminatory hiring practices or improving working conditions, prefer to circumvent this rigid labor market by lobbying governments to promote labor mobility. local, regional, national and foreign to rapidly increase the number of available workers.

As a result, more and more industrialized countries are opening up to migrant workers and adopting specific programs that meet the needs of businesses alone. The local or immigrant workforce does not find it in terms of working conditions. Immigration policies are diverted from their primary function, welcoming new citizens.

\section{A Return to Financial Control: Nationally and Internationally}

One of the most serious dangers of today's globalization is the hegemony of financial capitalism and its disruptions, such as the creation of questionable financial products, speculative bubbles, the excessive indebtedness of certain companies or spectacular fraud. Deregulation in recent decades is one of the first causes. Few national capital controls remain and global controls are virtually non-existent. It is high time to (re) regulate all the more since evidence of the effectiveness of regulation has historically been demonstrated.

Several analysts on the international financial scene, including the labor movement, are convinced that something must be done to minimize or even avoid the negative effects of financial disruption. Various means are suggested to harness finance again.

A first step would be to move financial markets away from speculation and short-term profits and to reorient them towards productive, job-creating investments. Various social movements have thus been the promoters of a financial tax, inspired by the Tobin tax on exchange rate transactions, which would be extended to all financial transactions. Its purpose would be to discourage speculation by making financial transactions more expensive in the very short term. This would have the effect of reducing the risks of too fast reversal of the stock or financial markets. What's more, the money raised by such a tax could serve the purpose of redistributing wealth. 
The supervision of investment funds is diversified. For example, institutional funds (pension plans, banks, insurance companies) are a little more supervised than some private or sovereign investment funds that, in fact, can do just about anything they want, too often in the greatest secrecy. For example, pension plans or banks are subject to so-called prudential rules, rules that encourage caution by limiting excessive risk-taking, such as guarantees that require them to keep a certain percentage of capital to cover risks in other investments or investing a certain predetermined percentage of their assets in safe investments such as bonds.

International trade union organizations, including the Trade Union Advisory Committee of the OECD (TUAC) and the International Trade Union Confederation, call on the international community, and more specifically the governments of the G8, to put in place international measures to address the lack of transparency and efficiency of capital market regulation. These unions support the importance of applying such regulations for all types of funds, including venture capital funds, hedge funds or sovereign wealth funds. Indeed, all investors should behave as "good citizens", take into account the social or environmental impacts of their investments and be subject to the regulations of the countries in which they invest. They also stress the importance of tightening the rules for investment in tax havens.

Governments must be alert to the negative effects of debt purchase for the productive fabric and the level of employment in their country, but also in terms of lost tax revenues. In several countries, including Canada, certain interest charges payable on the debt are deductible from business taxes. When a fund indebts a company to increase the return paid to the shareholders, tax deductions are claimed and the governments are deprived of significant income without being assured that these amounts are used for productive investments in the company.

In Denmark, after analyzing the tax returns of seven large companies that had been purchased by a venture capital fund, the government found that their tax bill had dropped significantly. Prior to their purchase by a private fund, these companies collectively paid $\$ 420$ million in taxes. In the year following the acquisition, only $\$ 70$ million was paid due to higher interest payments on the debt. The Danish government has estimated that this debt-purchase practice will cause it to lose up to $25 \%$ of tax revenue from business taxes in the very short term. One can only imagine the negative impacts on public services if government revenues fall significantly. Legislation has been adopted to restrict to smaller companies, which are thought to be less likely to interest speculators, the right to deduct interest.

\section{Conclusion}

Today's capitalism is different from that of the past by its almost limitless adherence to financial logic. This orientation leads to an economic situation which is difficult to sustain in the long term. Financial capitalism can not grow steadily when stock market prices fluctuate, while periods of high profitability follow or follow periods of sharp depreciation. And this, despite the good performance of the main economic indicators of a country or a healthy business situation. Mass layoffs also follow a stock market logic and not a logic of production or service delivery. Companies announcing large layoffs are seeing their equities flopped. As for the public sector, it is constantly under attack by supporters of the dogma of the free market. Defenders of this thesis claim - wrongly! the private sector does better than the public sector in all areas. Thus, the private sector would make investments generating wealth while the public sector would make only reckless expenditures. Some media and think tanks have orchestrated a campaign for the privatization of public services and a slimming cure for public sector jobs. Not to mention the obsession with balanced budgets and debt repayment to justify cuts in public spending. As a result, jobs are lost or precarious. The range of services is shrinking and the role of the state is increasingly diminished. At the very moment when we would have the greatest need for a strong State that would agree to regulate and regulate the globalization of trade and financial exchanges.

\section{References}

Amartya, S. (2001). Ten truths about globalization. Le Monde.

Baldwin, R., Kawai, M., \& Wignaraja, G. (eds.) (2013). The Future of the World Trading System: Asian Perspectives. A VoxEU.org eBook.

Clark, G., \& Farewell, A. (2008). Alms: A Brief Economic History of the World (p. 195).

Gopinath, G., Helpman, E., \& Rogoff, K. (2014). Handbook of International Economics (Vol. 4). Amsterdam, Elsevier.

Hatton, T. J., \& Jeffrey, G. W. (1998). The Age of Mass Migration: Causes and Economic Impact. USA: Oxford University Press.

Lipsey, R. E., Ramstetter, E. D., \& Blomström, M. (2000). Outward FDI and Parent Exports and Employment. 
NBER Working Paper, No. 7623.

Mundell, R. A. (1957). International Trade and Factor Mobility. The American Economic Review, 47(3), 321-335.

Panagariya, A. (2000). Evaluating the factor-content approach to measuring the effect of trade on wage inequality. Journal of International Economics, 50, 91-116. https://doi.org/10.1016/S0022-1996(99)00023-9

Stiglitz, J. E., Walsh, C. E., \& Lafay, J. D. (2012). Principles of Modern Economy (3rd ed).

Williamson, J. (1990). What Washington Means by Policy Reform. In J. Williamson (Ed.), Latin American Adjustement: How Much Has Happened? Washington, DC: Institute for International Economics. Retrieved from https://www.decitre.fr/media/pdf/feuilletage/9/7/8/2/8/0/4/1/9782804193744.pdf

\section{Copyrights}

Copyright for this article is retained by the author(s), with first publication rights granted to the journal.

This is an open-access article distributed under the terms and conditions of the Creative Commons Attribution license (http://creativecommons.org/licenses/by/4.0/). 